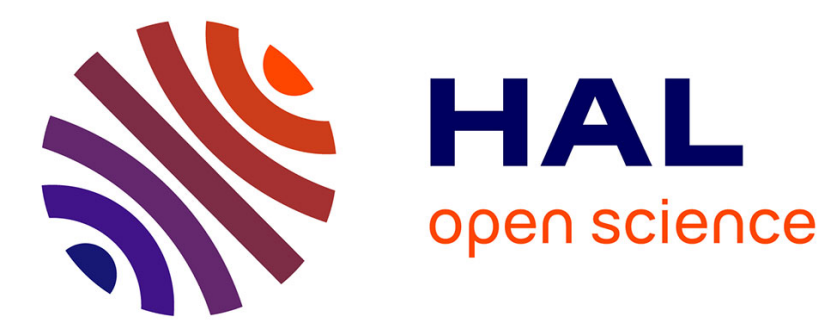

\title{
The Cultural Evolution of Oaths, Ordeals, and Lie Detectors
}

\author{
Hugo Mercier
}

\section{To cite this version:}

Hugo Mercier. The Cultural Evolution of Oaths, Ordeals, and Lie Detectors. Journal of Cognition and Culture, 2020, 20 (3-4), pp.159-187. 10.1163/15685373-12340080 . ijn_03080736

\section{HAL Id: ijn_03080736 \\ https://hal.science/ijn_03080736}

Submitted on 17 Dec 2020

HAL is a multi-disciplinary open access archive for the deposit and dissemination of scientific research documents, whether they are published or not. The documents may come from teaching and research institutions in France or abroad, or from public or private research centers.
L'archive ouverte pluridisciplinaire HAL, est destinée au dépôt et à la diffusion de documents scientifiques de niveau recherche, publiés ou non, émanant des établissements d'enseignement et de recherche français ou étrangers, des laboratoires publics ou privés. 
THE CULTURAL EVOLUTION OF OATHS, ORDEALS, AND LIE DETECTORS

ACCEPTED AT JOURNAL OF COGNITION AND CULTURE, NOT PROOFREAD

\author{
Mercier, $\mathrm{H}$. \\ Institut Jean Nicod, \\ Département d'études cognitives, \\ ENS, EHESS, PSL University, CNRS, \\ Paris France \\ hugo.mercier@gmail.com
}

\begin{abstract}
In many cultures oaths, ordeals, or lie detectors adjudicate in trials, even though they do not discern liars from truth-tellers. I suggest that these practices owe their cultural success to cognitive mechanisms that make them culturally attractive. Informal oaths trigger mechanisms of commitment in communication. Judicial oaths, by invoking supernatural punishments, trigger intuitions of immanent justice, linking misfortunes following an oath with perjury. These intuitions justify the infliction of costs on oath takers in a way that appears morally justified. Ordeals reflect the same logic. Intuitions about immanent justice link a worse outcome following the ordeal with a guilty verdict. This link justifies the application of the ordeal, and the fixed costs involved (burning, poisoning). Lie detectors also rely on the creation of a link between a specified outcome and a guilty verdict. However, they rely on a variety of intuitions ranging from the plausibly universal to the culturally idiosyncratic.
\end{abstract}

Keywords: Oaths, Ordeals, Lie Detectors, Cultural Attraction Theory, Immanent Justice, Commitment. 


\section{THE CULTURAL EVOLUTION OF OATHS, ORDEALS, AND LIE DETECTORS}

Throughout the world, people use a wide range of practices to decide on guilt or innocence, lying or truth-telling, some of which do not have obvious relations with the truth of the matter. Among the Igbo, a man accused of adultery could clear his name by swearing an oath to the ancestors, but if a misfortune then befell him, he was believed to have lied (Meek, 1937, p. 147). In eleventh-century Normandy, you could prove your innocence by carrying a red-hot iron without suffering from an infection following the burn (Bartlett, 1986, p. 20). Among the Manua, men suspected of a crime each had to place their hand on a coconut. After a ritual, one of the men's guilt would be indicated by an upside-down coconut (Mead, 1969, p. 170).

Some of these practices - like the coconut lie detector - appear to be culturally idiosyncratic. Others were found across the world: the hot iron ordeal was practiced not only in many early medieval European cultures (Bartlett, 1986), but also in dozens of African societies (RetelLaurentin, 1969; J. M. Roberts, 1965), and in some Asian cultures such as the Ifugao or the Ainu (J. M. Roberts, 1965). Oaths, in one form or another, were even more widespread, and still play a role in some modern judicial systems. The goal of this article is to explain why these practices prove so culturally successful. To do so, I rely on cultural attraction theory, presently exposed, and on an informal review of anthropological and historical work on oaths, ordeals, and lie-detectors (for a similar approach on divination, see P. Boyer, in press). In spite of its informality, this review covers a very wide range of historical and anthropological evidence and stems from an honest attempt at comprehensiveness. 
OATHS, ORDEALS, AND LIE DETECTORS

\section{Factors of attraction}

Oaths, ordeals, and lie detectors are commonly found in oral cultures. Even when some members of the culture were literate (e.g. early medieval Europe), and there were written laws, "legal process often remain[ed] largely oral," as they were grounded in oral traditions and discussions within the largely illiterate community (Hyams, 1981, p. 96). The high degree of transmission noise inherent in human communication raises some well-known challenges for the spread and persistence over generations of cultural elements (see, e.g., Sperber, 1996).

Sperber and his colleagues have suggested that the success of cultural elements, in the face of this transmission noise, is determined by factors of attractions (e.g. Claidière \& Sperber, 2007; Morin, 2016; Sperber, 1996). These factors of attraction affect the probability that individual variants of a cultural item depart from their model in one direction rather than another. If a factor of attraction is consistent across time and space, it systematically leads cultural variants towards the same point (an attractor), such that cultural variants that correspond to this attractor are more likely to be successful. For example, it has been suggested that the cultural success of the medical practice of bloodletting is due to a conjunction of cognitive factors of attraction (e.g. related to the psychology of disgust) (Miton, Claidière, \& Mercier, 2015; for other examples, see Claidière, Smith, Kirby, \& Fagot, 2014; Griffiths, Kalish, \& Lewandowsky, 2008; Kirby, Cornish, \& Smith, 2008; Morin, 2013; Reali \& Griffiths, 2009).

Factors of attraction can take many shapes: they can be ecological (e.g. which materials are available) or cognitive (e.g. which story is easier to remember), local (e.g. the local topology, culturally idiosyncratic beliefs), or general (e.g. the laws of physics, universally developing 
OATHS, ORDEALS, AND LIE DETECTORS

cognitive mechanisms). Given that oaths, ordeals, and (to a lesser extent) lie detectors are present in many different environments, and have persisted over many generations, we can surmise that some general cognitive factors of attraction played a significant role in their success (Morin, 2016). Presently, two cognitive mechanisms are introduced that, I will argue, help explain the cultural success of oaths and ordeals.

\subsection{Commitment in communication}

Because of the risks involved in relying on communication, humans are endowed with a suite of cognitive mechanisms aimed at evaluating communicated information (Mercier, in press, 2017; Sperber et al., 2010). One of the tasks of these epistemic vigilance mechanisms is to keep track of who said what, in order to lower our trust in people who provided unreliable information. By doing so, epistemic vigilance also provides speakers with a way of getting their messages across: modulating how much they commit to their messages. A highly committed speaker would suffer a more significant loss of trust if the information she provided turned out unreliable, thereby providing her interlocutor with a reason to accept the message, at least provisionally. We can see this dynamic at play in the communication of confidence. Speakers who express themselves more confidently are believed more. However, speakers who proved overconfident (i.e. confident and yet wrong) suffered from a more severe loss of trust than speakers who were equally wrong but less confident (Tenney, MacCoun, Spellman, \& Hastie, 2007; Vullioud, Clément, Scott-Phillips, \& Mercier, 2016).

The value put on a speaker's degree of commitment should depend on two main variables. Commitment is persuasive because of the risks that the speaker loses the trust of her interlocutor, and, by extension, the trust of people her interlocutor might influence. The value 
OATHS, ORDEALS, AND LIE DETECTORS

of a speaker's commitment should thus be heavily modulated by the perceived value, for the speaker, of long-term cooperation with her interlocutor and those her interlocutor can influence. We should put more weight on the commitment of someone we expect to cooperate with a lot with in the future, than on the commitment of someone we'll never see again.

The second relevant variable is the odds that the speaker could be found out as having provided unreliable information. In the cases of promises, interlocutors can wait to see whether the speaker will be true to her words. In the case of statements about the past, commitment should be mostly persuasive when the interlocutor could check whether the speaker is lying or not. Believing the speaker saves the interlocutor the effort of checking, and the speaker's honesty is motivated by the fact that the interlocutor could potentially check. On the whole, evidence from experimental psychology suggests that people use commitment to evaluate speakers in a broadly appropriate fashion, so that commitment enables the efficient transmission of information (Bahrami et al., 2010; Mercier, in press, 2017).

The psychological mechanisms dealing with commitment are a factor of attraction as they contribute to the cultural success of the means of communicating commitment. For example, human languages possess expressions (e.g. "I'm sure") and grammatical markers (e.g. modals, evidentials) that evolved culturally at least in part as means of communicating commitment (see, e.g. Fusaroli et al., 2012).

\subsection{Immanent justice}

Anthropologists and psychologists have noted the recurrent human tendency to believe in immanent justice: that good deeds are rewarded, and bad deeds punished, even without human 


\section{OATHS, ORDEALS, AND LIE DETECTORS}

agency. Beliefs in immanent justice are a staple of many religions, and these beliefs are used across the world to explain a range of negative outcomes, such as diseases (Callan, Sutton, Harvey, \& Dawtry, 2014; Murdock, 1980; Shweder, Much, Mahapatra, \& Park, 1997). Besides explicit beliefs in immanent justice, experiments have revealed the existence of an underlying intuition causally linking bad deeds and bad outcomes, intuition which can be triggered even in the absence of explicit beliefs in immanent justice. For example, North American participants were more likely to draw such a link when they were put under cognitive load, and thus could not access their explicit belief that immanent justice does not exist (Callan, Sutton, \& Dovale, 2010). Similar participants also tended to spontaneously anticipate - by orientating towards it in a visual scene - a bad outcome when a protagonist had engaged in a bad deed (Callan, Ferguson, \& Bindemann, 2013).

Baumard and Chevallier (2012) have argued that intuitions of immanent justice stem from intuitions about fairness. On this basis, they predicted and observed that people more spontaneously draw immanent justice inferences when the bad deeds and the bad outcomes are proportional (e.g. insulting a beggar and falling down vs. dying in a car accident). These intuitions about fairness would be one of the main factors of attraction explaining the cultural success of beliefs in immanent justice. However, by contrast with intuitions about fairness, which play a crucial role in our behaviors and inferences (Baumard, André, \& Sperber, 2013), explicit beliefs in immanent justice would be mostly reflective, playing a limited in our behaviors and inferences, except for communicative behaviors (Baumard \& Boyer, 2013b; Sperber, 1997).

Reviewing the literature on how oaths, ordeals, and lie detectors are used to make decisions about guilt and innocence, lying and truth-telling, the core of this article is an attempt to 
OATHS, ORDEALS, AND LIE DETECTORS

explain the cultural success of these practices by referring to cognitive factors of attraction, related - inter alia — to intuitions about commitment and immanent justice.

\section{Oaths}

In its dictionary definition, an oath is "a solemn, usually formal calling upon God or a god to witness to the truth of what one says or to witness that one sincerely intends to do what one says" (Webster definition cited by J. M. Roberts, 1965, p. 186). However, many cultures possess oaths with no explicit link to the supernatural: U.S. politicians can swear an oath on the Constitution, a Barotse can swear "by the king" (Gluckman, 1967, p. 100). A stark distinction between these expressions and oaths with a link to the supernatural would be artificial. As a result, I define here an oath as a culturally accepted way of unambiguously signaling a maximum degree of commitment.

Under this definition (or even the dictionary one), oaths can be found in many contexts besides that of a trial (see Silving, 1959): there are fealty oaths, promissory oaths, oaths of fidelity (e.g. Beattie, 1960), oaths in initiation ceremonies (Roscoe, 1924), and oaths sworn in less formal circumstances. Oaths are incredibly culturally resilient. Not only are oaths prevalent worldwide, but they can persist over centuries, even in the toughest conditions for cultural transmission: children's cultures and their rapid generational turnaround (see Morin, 2016). The children studied by the Opie in the mid-twentieth century still used oaths from early-modern Scotland, and some that might even have survived from Roman times (Opie \& Opie, 2001 chapter 8). 
OATHS, ORDEALS, AND LIE DETECTORS

Before turning to the specific properties of the judicial oath (this encompasses a variety of oaths: assertory, decisory, suppletory, see Silving, 1959), I suggest an explanation for why oaths more generally would be so culturally robust and prevalent, since this broader success provides a necessary background for the more restricted judicial use of oaths.

\subsection{Oaths as noise-proof commitment devices}

As explained above, humans are equipped with a variety of means for communicating their degree of commitment, from tone to explicit expressions. People also modulate their expression and understanding of commitment as a function of context: the same statement can indicate very different degrees of commitment in a drunken chat or a high-level meeting. However, the subtlety of some expressions of commitment, and their contextual modulation, make it difficult to accurately relay to a third party the degree of commitment of our interlocutors (e.g. "She sounded sure, and in context it was clear she was serious" might fail to convey the original speaker's degree of commitment). This difficulty is amplified by each new episode of transmission.

Commitment is persuasive when the speaker's reputation is at stake. The more people (who matter to the speaker) are aware of a speakers' commitment, the more persuasive it is. One solution for a speaker to make her commitment more persuasive is thus to make her degree of commitment easier to communicate beyond the immediate context of the discussion, thereby enlarging the circle of people who can judge her negatively if she defaults on her commitment. 


\section{OATHS, ORDEALS, AND LIE DETECTORS}

In this context, an expression that is easy to convey beyond the immediate discussion and that indicates a maximal degree of commitment would be useful for speakers. ${ }^{1}$ I suggest that this is the main reason people use oaths: as a way of indicating a maximum degree of commitment in an easily transmissible manner. As the need for easy ways of transmitting expressions of commitment arises, their cultural success is facilitated by the convergence between what makes an oath optimal for its taker (i.e. that the audience finds it memorable and easy to transmit), and what makes a practice culturally successful (i.e. that it be memorable and easy to transmit). By contrast, for most cultural contents, there are conflicts between what is locally optimal and what is most likely to be culturally successful (for example, the best jokes might be jokes that are long, difficult to tell, and only work with a specific audience, but such jokes are unlikely to be well remembered or widely transmitted).

If oaths are noise-proof commitment devices, they should be least common in the smallestscale cultures, since there would typically be fewer episodes of transmission, making the problem of transmission noise a less pressing one. This seems to be the case: the presence of oaths in a culture is associated with a higher degree of political integration, and thus a larger size (J. M. Roberts, 1965, p. 192).

The cultural success of oaths might be facilitated by the fact that human episodic memory appears geared towards remembering precisely the type of high stake social contexts in which oaths are typically uttered (Mahr \& Csibra, 2017). Moreover, oaths often take forms that make them easier to memorize. Some involve rhyming (e.g. Opie \& Opie, 2001, p. 141). Many involve some act likely to trigger disgust, which is known to help cultural elements survive by making them particularly memorable (Eriksson \& Coultas, 2014; Heath, Bell, \&

\footnotetext{
${ }^{1}$ Note as well that such an expression is mostly useful for a maximal degree of commitment, and not other degrees of commitment, since the goal is to go beyond the maximal degree of commitment one can attain with other means of communicating commitment.
} 
OATHS, ORDEALS, AND LIE DETECTORS

Sternberg, 2001; Nichols, 2002): the Haya had to touch the chief's forehead with their tongue (Cory \& Hartnoll, 1945, p. 271), the Nuer had to lick a spear (Evans-Pritchard, 1956, p. 297), the Kikuyu had to lick "a brushful of the contents of a lamb's stomach mixed with sacred herbs," (Middleton, 1953, p. 48), the Igbo had an accused murderer drink some of the water used to wash his alleged victim's corpse (Basden, 1966, p. 259), and the English children observed by the Opie would spit on the ground, or lick their thumbs (Opie \& Opie, 2001, p. 129). Although there is cultural variability in what elicits disgust, if its evolved function is pathogen avoidance (see, e.g. Curtis, Aunger, \& Rabie, 2004), it should be triggered by all of these behaviors — or at least be triggered when people first engage in them.

There is some evidence that, in informal settings, oaths work. For example, an observer reports that, among the !Kung, a hunter suspected of not having fully participated in the hunt would swear "by the great captain nu $\chi \mathrm{u}$, and all [would] believe him" (Lebzelter, 1934, p. 109). Experimental results show that U.S. and French participants take promises (which can be considered as a weak form of oath), as well as oaths seriously when playing trust games or similar economic games, even in the absence of possibility to punish liars (Charness \& Dufwenberg, 2006; Jacquemet, Luchini, Shogren, \& Zylbersztejn, 2018; see also Balliet, 2010; Ostrom, Walker, \& Gardner, 1992).

If one of the main uses of oaths is as noise-proof commitment devices, then they should mostly be used when we expect commitment to be effective. This means that oaths should only be useful for people who have a reputation to uphold in front of the people they are swearing the oath. On the whole, this seems to be the case: in many cultures, individuals whose reputation were thought to be inconsequential — foreigners, slaves, minors, sometimes women—could not swear oaths (Ancient Greece: Bonner, 1905, p. 27, Harrison, 1971, p. 
OATHS, ORDEALS, AND LIE DETECTORS

136ff; Ancient Middle-East: G. Boyer, 1964, p. 74; Ancient Muslim law: Brunschvig, 1964, p. 171; Medieval Europe: Davies \& Fouracre, 1992, p. 177, Olson, 2000, p. 180). Likewise, people who've already defaulted on their oaths should see the value of their oaths drastically reduced, or eliminated. As expected, one of the punishments for perjury was to not be able to swear oaths anymore (Medieval Europe: Davies \& Fouracre, 1992, p. 177, Olson, 2000, p. 121, see also, Fisher, 1997, p. 654).

Another factor constraining the power of commitment is the odds of finding out whether the speaker will be proven wrong. In the example above from the !Kung, we can presume that the oath taker's audience might have the means of checking whether he participated in the hunt or was gallivanting. This possibility makes the oath credible. However, judicial oaths are, by definition, used in the context of trials. Trials are usually high-stake affairs, and the parties as well as the judge(s) have an incentive to expand reasonable efforts finding out the truth of the matter. One of the strongest cross-cultural regularities in the use of judicial oaths is that they are only used to render a verdict as a last recourse, when no conclusive evidence could be found (for example, in cases of adultery, which tend to have few witnesses) (Mende: Allott, 1964, p. 75; early Middle-East: G. Boyer, 1964, p. 83; early Mulsim: Brunschvig, 1964, p. 176; Visigoths: Diamond, 2004, loc. 8402, Franks: 2004, loc 8338; Japanese under the Kamakura shogunate: Ishii, 1964, p. 526; Igbo: Meek, 1937, p. 147; ancient Hindus: Rocher, 1964, p. 335; early Anglo-Saxons: Shack, 1979, p. 2). The few exceptions, such as Germanic law (Silving, 1959, p. 1340), or later Anglo-Saxon law (Shack, 1979), in which the oath could trump some evidence, can be explained by the use of the oaths I'll turn to next: the oath as power move. 


\section{OATHS, ORDEALS, AND LIE DETECTORS}

The use of the oath as a last recourse, when conclusive evidence cannot be found, should be puzzling. By the logic of commitment exposed earlier, when it is impossible to tell whether the oath taker is lying (because the evidence has been exhausted), the oath should be unconvincing. Swearing to something that the judges or the audience can never check is quintessential cheap talk. In this context, it is not surprising that some cultures have oaths, but grant them little or no weight in trial procedures (ancient Athens: Bonner, 1905, p. 77; Harrison, 1971, p. 153; Gauls: Davies \& Fouracre, 1992, p. 15; late medieval England: Fisher, 1997; Barotse: Gluckman, 1967, p. 100; Shona: Holleman, 1975, p. 82; Barundi: Meyer, 1916, p. 148; Tswana: Schapera, 1955, p. 289). What is surprising is that some cultures do take judicial oaths to be decisive, even if they only do so in the absence of other compelling evidence.

\subsection{Oaths as power moves}

To make their statements more convincing, people often explain how they acquired their beliefs, saying "I’ve seen John kiss Kelly," rather than "John and Kelly are dating."2 This strategy works because it largely rules out one cause for an inaccurate statement: incompetence. If the speaker cannot have made a mistake when seeing John kiss Kelly, then we must either believe them or question their intentions, i.e. suggest they might be lying.

Committing to statements whose inaccuracy could not be explained by incompetence has two main effects. The first is to make the statements more persuasive, to the extent that the audience doesn't suspect the speaker of lying. The second is to make it more socially costly to

\footnotetext{
${ }^{2}$ Indeed, providing information about the sources of our statements is grammatically mandatory in the many languages with evidentials (Aikhenvald, 2004). In this context, the markers that should indicate the strongest evidence, and leave the least room for an explanation in terms of incompetence, are markers of egophoricity (Floyd, Norcliffe, \& San Roque, 2018), when a speaker describes something they have privileged access to, which is the type of information most oaths bear on (e.g. "I did not sleep with him").
} 


\section{OATHS, ORDEALS, AND LIE DETECTORS}

question such statements. Questioning someone who says "John and Kelly are dating" is acceptable: they might have heard a mistaken rumor, drawn a faulty inference, etc. By contrast, questioning someone who says "I've seen John kiss Kelly" amounts to calling them a liar, something not done lightly. In several cultures calling someone a liar is slander, punishable by law (in theory many contemporary cultures, but see also, e.g. old MiddleEastern laws: G. Boyer, 1964, p. 77; medieval Icelandic laws: Miller, 1988, p. 207).

Oaths are often taken on statements for which one could hardly be merely mistaken — e.g. "I swear I did not sleep with her"-making it socially costly to question the oath taker, especially since the oath communicates a maximum degree of commitment. Swearing an oath can thus become a power move, a gambit at least, attempting to force the audience's overt assent. This power move is useful independently of any persuasive effect the oath might have. By stopping people from questioning the speaker, it can preclude audience members from realizing their doubts are shared. ${ }^{3}$ More relevantly here, when a decision hinges on whose word is accepted - as in the case of a trial — the oath might tilt the decision towards an oath taker that no one dares question.

When used as a power move, the oath shifts from being about what is true to being about the costs the oath taker is willing to pay to prevail in a conflict. The oath taker is signaling that he would be offended, and that he might retaliate, if his oath is not taken seriously (as if the oath were an expression of anger, see Sell et al., 2017; Sell, Tooby, \& Cosmides, 2009). To be effective, the oath as a power move should be sworn by someone in a position to inflict some costs on people who would dare question them (someone with sufficient formidability, in the terms of Sell et al. 2009). To some extent, the constraints linked to the power of the oath taker

\footnotetext{
${ }^{3}$ It is obviously still possible for audience members to talk behind the speaker's back (see e.g. Boehm, 1999, on the importance of gossip to control bullies), but that makes coordination more difficult.
} 
converge with the constraints based on credible commitment: it is typically the powerful members of society who are thought to stand to lose by jeopardizing their reputation. ${ }^{4}$

In societies structured along kin-based groups, the oath as a power move sometimes takes the form of compurgation: the oath-taker must gather the support of a given (sometimes large) number of co-oath takers (compurgators) for their oath to be valid. Compurgation can be found in many European societies in the first millennium (Shack, 1979; and in some places, such as Montenegro, up to the $19^{\text {th }}$ century, see Boehm, 1987, p. 123), in early Islamic law (Hamidullah, 1964, p. 192), and in many African cultures (Shack, 1979). Since compurgators are chosen based on their relationship with the oath-taker, rather than because they have knowledge of relevant facts, compurgation reveals how much oaths have become pure power moves in some cultures. However, the exercise of power through oath taking is still limited: someone who would swear an oath in blatant disregard for a commonly accepted truth would not only fail to convince or impress, they would also lose some status (for an early medieval Europe example, see, Davies \& Fouracre, 1992, p. 177). Likewise, in some cultures the power asymmetry is so large that a power holder can swear to things they could hardly be sure about, as when the Zande king swears an oath that someone is innocent-but even in this case, the king appears to be bound by some informal rules of plausibility (Evans-Pritchard, 1957).

\subsection{Oaths and supernatural punishments}

When oaths are used as power moves, one party indicates its willingness to pay some costs (in the form of retaliation against those who would question their oath) to prevail in the conflict. However, the balance of power is often not asymmetric enough that one party can simply get

\footnotetext{
${ }^{4}$ Medieval Ireland provides a clear example, see Davies \& Fouracre, 1992, p. 177.
} 


\section{OATHS, ORDEALS, AND LIE DETECTORS}

its way by swearing an oath. Indeed, often both parties swear an oath (for examples of African customary law: Allott, 1964, p. 75; early Muslim law: Brunschvig, 1964, p. 179), meaning that one of the oaths is a perjury. Indeed, contemporary commentators often deplored the prevalence of perjury (for ancient Athens, see sources cited in Bonner, 1905, p. 88; medieval Europe: Davies \& Fouracre, 1992, p. 16; Kerr, Forsyth, \& Plyley, 1992, p. 574; Shack, 1979). In societies in which one third party (the king, the state) yields sufficient power, this third party can attempt to impose heavy punishments for perjury (e.g. Rwanda: Czekanowski, 1917; early criminal codes, such as Jewish or Frankish: Diamond, 2004, pp. 1661, 2271, 8573). However, if no evidence has been found at the time of the trial, we can assume that relevant evidence would only rarely surface afterwards, severely reducing the dissuasive power of these penalties for perjury. ${ }^{5}$

If a significant goal of the trial is conflict resolution (see, e.g., G. Boyer, 1964; Conner, 2000, p. 147; Holleman, 1975; and, more generally, S. Roberts, 1979), and if the trial has reached a point at which the truth of the matter cannot be obtained with sufficient certainty, the most relevant information becomes how much each party would be willing to pay to prevail. Merely asking the parties would not do, as their responses would be cheap talk: they could both say they would be willing to pay high costs, without suffering any negative consequences for their exaggerations. I argue that the link between oaths and supernatural punishments helps address this problem.

Not only are oaths often sworn on a divinity, but many oaths mention some form of punishment that the oath taker would suffer in case of perjury. For example, a Barotse man accused of adultery might claim "May I split inside if I was her lover" (Gluckman, 1967, p.

\footnotetext{
${ }^{5}$ Although the possibility of finding evidence after the trial was certainly considered, see, e.g., Lévy, 1964, for medieval Europe.
} 
OATHS, ORDEALS, AND LIE DETECTORS

101). The link between perjury and misfortune is made intuitively compelling by our intuitions about immanent justice. These intuitions make stories about perjurers suffering misfortunes attractive: more memorable, more interesting to transmit, and more likely to be the end point of a transformation process. Indeed, stories about perjurers suffering misfortunes are often found in cultures that use oaths (e.g. medieval Europe: Davies \& Fouracre, 1992, p. 15; Olson, 2000 note 53; $20^{\text {th }}$ century Europe: Opie \& Opie, 2001, p. $121 \mathrm{ff})$. If a link between perjury and misfortune is easily drawn, it can help make oaths more credible.

The most obvious way in which a belief in immanent justice could strengthen the credibility of oaths is if this belief were thought to be fully held by oath takers. If oath takers were thought to truly believe perjury would bring misfortune upon them, then they should be expected to not perjure themselves. However, this is not very plausible, for several reasons, which are only sketched here since they are presented at length in the next section related to ordeals. When people hold explicit beliefs about immanent justice, they are held reflectively: they emerge and stabilize because they tap into our intuitions, but they do not guide our inferences or our behaviors (Baumard \& Boyer, 2013b). Holding beliefs in immanent justice, by and large, does not stop people from misbehaving in a variety of ways. Moreover, if faking a belief in immanent justice were all it took to become very credible, the signal would promptly be abused and become useless.

Instead, I argue that intuitions about immanent justice play a more indirect role in the success of oaths with supernatural punishments. What matters is not the conditional as presented ("If I lie, something bad will happen to me"), but its converse used as a diagnostic tool ("If 
something bad happens to me, it means I lied"). What matters is not the cost of the misfortune befalling a perjurer, but the costs imposed by the community following the misfortune.

As mentioned above, a crucial piece of information for conflict resolution is how much each party would be willing to pay to prevail. However, simply asking the parties to pay up (in one form or another) in order to prevail would violate intuitions about fairness (Baumard et al., 2013). ${ }^{6}$ Moreover, in a context in which the accused knows whether they are innocent or not, negotiating a compromise is likely to be perceived as an admission of guilt (when in fact it might only reflect the impossibility of proving their innocence). ${ }^{7}$ A solution is to find a way of linking the payment of costs to the facts of the matter relevant to the decision, and thus to what would be a fair decision: to make it look as if the party paying the cost does so because they were in the wrong. Oaths with supernatural punishment do exactly this. A party who swears such an oath pays a cost: not in the increased risk of misfortune (obviously), but in the increased cost of misfortune, since if a misfortune does befall the oath taker, they will be thought to have lied, and thus treated as perjurers.

Under this hypothesis, intuitions about immanent justice create a focal point (Schelling, 1960), allowing group members to agree on a way of making oaths costlier but still apparently fair. People don’t have to hold a strong belief that a perjurer will necessarily suffer from a misfortune. All that matters is that the intuition "misfortune indicates perjury" should be common knowledge: that people expect other people to find it suspect when a misfortune befalls an oath-taker.

\footnotetext{
${ }^{6}$ These intuitions also explain, for instance, why out of court settlements appear morally problematic: they reflect strategic reasoning in a domain which we hope to be ruled by morality.

${ }^{7}$ This explains in part at least why some people find Alford pleas, in which a defendant pleads guilty while claiming his innocence, problematic (e.g. Bibas, 2002).
} 
By increasing the costs borne by oath takers, oaths with supernatural punishments are useful in several ways. They are useful for oath takers because they provide a socially acceptable way of incurring some costs in order to prevail in a conflict. In turn, this provides valuable information to judges and community members regarding who wants to prevail the most, and thus how to best settle the conflict. Moreover, the very fact that oath takers pay a cost can help solve the conflict by assuaging the other party: they lose the battle (the immediate verdict), but might still win the war (in case of a misfortune befalls the other party, the outcome will be reversed).

The hypothesis that misfortunes are used as a focal point to coordinate on a way of inflicting costs on oath takers is supported by the existence of two equilibria regarding oaths with supernatural punishments. One equilibrium is that just described, in which the mention of potential supernatural punishment becomes a genuine cost. In this equilibrium, we often find agreed upon rules regarding (i) the misfortunes taken to diagnose perjury, (ii) the time frame in which these misfortunes diagnose perjury, and (iii) the penalties for perjurers. For example, among the Ibo the misfortunes that diagnose perjury are the death of the oath taker, his wife, or his eldest son, which must take place at most six months after the oath was taken (Allott, 1964, p. 75). By contrast, the Hindu laws of Manu specified laxer criteria regarding misfortunes — sickness was sufficient— but also a shorter time frame — seven days (Rocher, 1964, p. 346) (see also, medieval Japan: Ishii, 1964, p. 526; Kikuyu: Middleton, 1953, p. 48). In these cultures, someone believed to be a perjurer because of a diagnostic misfortune would not only have to pay as if they had lost the trial, but they would also suffer additional penalties. 
However, there is another equilibrium, in which the mention of supernatural punishment has no discernible effects: what we would expect in the absence of an agreed upon framework for inflicting costs on oath takers who suffer from a misfortune. This equilibrium is observed for instance among the Barotse: they swear typical oaths with supernatural punishments, but perjury indicated by misfortune is not punished, and as a result judges "attach ... no more credibility to evidence thus affirmed than to evidence given without an oath" (Gluckman, 1967, p. 101, see above for other examples of culture that grant oaths no special weight). In this equilibrium mentions of supernatural punishment persist, in spite of their judicial inertness, because they are culturally attractive, in the same way as stories about immanent justice are attractive.

\section{Ordeals}

Ordeals are "a primitive means used to determine guilt or innocence by submitting the accused to dangerous or painful tests believed to be under supernatural control" (Webster, cited by J. M. Roberts, 1965, p. 186). However, I will use here a less inclusive definition that captures interesting similarities between the most common forms of ordeals. In addition to the definition above, to be considered an ordeal here, a procedure has to be "dependent upon involuntary responses"—-what Roberts (1965) called autonomous ordeals. Moreover, guilt has to be associated with a worse (e.g. more painful) outcome than innocence.

We find under this more restricted definition the most common and long-lasting forms of ordeals: burning (e.g. having to hold a red-hot iron for a given period of time), scalding (e.g. having to fetch an object from the bottom of a pot of boiling water), and poison (e.g. ingesting a poisonous substance). These practices were found in a wide range of cultures (Bartlett, 
OATHS, ORDEALS, AND LIE DETECTORS

1986; Retel-Laurentin, 1969; J. M. Roberts, 1965). Other practices usually referred to as ordeals - the cold water ordeal, the corsned ordeal, etc.- - are discussed in the next section on lie detection.

Ordeals have many features helping them persist in oral cultures. Even if ordeals are used less frequently than oaths, they are much more striking. This is obviously true for the individual who undergoes the ordeal, who will have the pain seared in her flesh and mind-whether she passes the ordeal or not (Erskine, Morley, \& Pearce, 1990; Morley, 1993). Even the poison ordeal is bound to be a very memorable moment, thanks to cognitive mechanisms dedicated to remembering toxin ingestion (Rozin \& Fallon, 1987). Those who witnessed ordeals would also have been deeply impressed: in order to learn vicariously, we are very attentive to, and remember well, what hurts or poisons others (e.g. Goubert, Vlaeyen, Crombez, \& Craig, 2011; Logue, Ophir, \& Strauss, 1981). In many societies, ordeals were very public events, “to which everyone flocked" (medieval Europe: Brown, 1975, p. 138; see also Hyams, 1981, p. 111). Ordeals were so striking that they became a staple of medieval literature (Bartlett, 1986, p. 18ff), and that centuries after the practice has disappeared we still find expressions such as "I would put my hand in the fire."

\subsection{Ordeals as a rational response to irrational beliefs}

Three types of explanations have been provided for the existence of ordeals. The first is that ordeals reflect the irrational beliefs held by more 'primitive' people. This explanation was dominant in legal history until the last quarter of the twentieth century (Van Caenegem, 1990; more recently, see Posner, 1998). Recently, Leeson (2012; see also Leeson \& Coyne, 2012)

\footnotetext{
${ }^{8}$ Common French saying: "J'en mettrais la main au feu."
} 
OATHS, ORDEALS, AND LIE DETECTORS

offered a new, more refined take on this explanation (for a precursor, see Thomas, 1971, p. 260). Leeson claims that the belief in immanent justice and, more generally, in the benevolence and power of God, was so strong in early medieval Europe that it was recruited by the clergy to make of ordeals an actual test of guilt. By this logic, the innocent would be willing to undergo the ordeal — since they would expect to escape unscathed — while the guilty would refuse and confess. The ordeal would then be rigged so that those who accept to take it would mostly pass.

One of Leeson's strongest argument is that many people passed the ordeal, which he claims shouldn't happen it if weren't rigged. However, Kerr et al. (1992) show that ordeals could be passed without being rigged. In the case of the hot iron ordeal, the test was whether or not the hand was infected three days after the ordeal. The most severe burns would be visually hard to distinguish from not having been burnt and, in any case, infections typically only occur after the third day. Recent witnesses of ordeals have reported on instances in which the ordeal was clearly not rigged, and yet was passed (India: Ravenhill, 1953).

Leeson claims that ordeals, in their rigged form, were most often applied to the innocent, as the guilty would confess rather than undergo the ordeal. However, in at least one relevant society (early medieval England), ordeals seem to have mostly been inflicted on people believed to be guilty (Kerr et al., 1992, p. 577; Reynolds, 1997, p. 25). Since ordeals were often passed, this created some mismatches, which had to be explained away (Olson, 2000, p. 141).

More generally, it is difficult to imagine that the faith of the people who had to undergo the ordeal would be sufficient to make the innocent among them believe they would walk away 
OATHS, ORDEALS, AND LIE DETECTORS

unscathed from such an obviously painful trial. Ordeals were most often practiced in places in which the gods were represented as human-like entities with little interest in delivering justice for justice's sake (Baumard \& Boyer, 2013a; P. Boyer, 2001). As Miller put it regarding medieval Iceland: "The God of day-to-day life was not held to the standards of the God of theologians. He could equivocate and he could be tricked, rather like human judges and juries" (Miller, 1988, p. 204).

Leeson's theory requires an immense faith in God, but also that the clergy carries out the procedure properly. This faith is hard to reconcile with the widespread stories of bribery, cheating, and negotiation over the outcome present in early medieval Europe (Bartlett, 1986; Brown, 1975, p. 139; Hyams, 1981, p. 94; Van Caenegem, 1965, p. 307; for other examples, see, Ibos: Basden, 1966, p. 225; Ila: Smith \& Dale, 1920, p. 356). Moreover, "every civilian could see that Roman law ignored [the ordeals]" (Van Caenegem, 1990, p. 273): if the clergy truly believed in the ordeals, why were they not used on churchmen? Finally, as noted on the oath section, contemporary commentators noted how widespread perjury was (see also Lévy, 1964, pp. 20-21). If God didn't intervene to strike down the takers of false oaths, why would he intervene in ordeals?

\subsection{Ordeals, consensus, power, and immanent justice}

Two explanations have been suggested to replace the view of ordeals as stemming from irrational beliefs. The first is that ordeals served a role of conflict resolution and consensusbuilding. ${ }^{9}$ By deferring to the judgment of god rather than to human judgment, ordeals would

\footnotetext{
${ }^{9}$ Adam Smith was an early proponent of this view (see Bartlett, 1986, p. 159).
} 
OATHS, ORDEALS, AND LIE DETECTORS

help put an end to the feuds that plague societies based along kin-groups (Brown, 1975; Hyams, 1981).

One issue with the conflict resolution/consensus-building explanation, pointed out by Bartlett (1986), is that, according to this explanation, it is mostly politically significant individuals who should undergo the ordeal. However, in reality the people undergoing the ordeal often were people who had little power, and played little or no political role (see below for more details). In such cases, the dispute at the origin of the ordeal would have been less likely to degenerate into a full-blown feud.

Instead of conflict resolution, Bartlett suggested that ordeals — at least as they were practiced in early medieval Europe —were a way of asserting power, a form of punishment (Bartlett, 1986). As we will see below, this explanation fits with some facts about how ordeals are typically practiced, but not others. In particular, under Bartlett's explanation, we would expect ordeals to be more common in societies with a stronger authority system, that can afford to inflict such a punishment, but ordeals are most likely to be found "where there is something of a general, but weak, authority system" (J. M. Roberts, 1965, p. 208).

The explanation I defend here combines aspects of the three previous explanations: irrational beliefs, conflict resolution/consensus building, and power assertion. I suggest that the success of the ordeal rests on the same psychological mechanisms as the oath with supernatural punishment used to deliver a verdict. Like these oaths, the ordeal is used as a last recourse, when no other evidence can be found (Gluckman, 1967, p. 98; Kerr et al., 1992, p. 574; Leeson, 2012). Like these oaths, the ordeal is mostly useful when the dispute has become public, making negotiations less likely to succeed (e.g. medieval Iceland: Miller, 1988, p. 


\section{OATHS, ORDEALS, AND LIE DETECTORS}

205). Like these oaths, the ordeal uses intuitions about immanent justice as a diagnostic mechanism: the innocent is supposed to suffer less than the guilty from the ordeal.

The importance of intuitions about immanent justice in ordeals is highlighted by the fact that the most common forms of ordeals involve as little human agency as possible. ${ }^{10}$ Those who administer the ordeal do not directly injure the accused: it is the accused who must seize the red hot iron, plunge her hand in the boiling water, or ingest the poison. And even the accused have no agency beyond this basic act, as the reaction is autonomic: whether infection occurs, blisters form, or the poison take effects. The constraint of making the ordeal appear to involve as little human agency as possible, along with ecological constraints on the materials available explain why only a very limited range of ordeals exist worldwide (burning, scalding, poison).

There are some exceptions to this pattern. In some cultures, the agency of those administering the ordeal is more transparent, for example when a king or a medicine man applies the red hot utensil to the accused (Haya: Cory \& Hartnoll, 1945, p. 272). In other cultures, the agency of the accused plays a paramount role, as in trial by battle (early medieval Europe: Leeson, 2011; Russell, 1959). ${ }^{11}$ But, compared to the canonical forms of the ordeal, both types of practices are rare (Bartlett, 1986; J. M. Roberts, 1965).

The importance of intuitions about immanent justice can be associated with the view that the ordeal rests on 'irrational' beliefs. However, contra Leeson, beliefs in immanent justice are not strong enough to make of the ordeal an efficient way of telling the guilty from the innocent (see above). Instead, these beliefs play an indirect role, creating a focal point that

\footnotetext{
${ }^{10}$ In the context of divination, Boyer refers to this phenomenon as "ostensive detachment" (P. Boyer, in press).

${ }^{11}$ See also the ordeal of the cross under Charlemagne - whomever could stay the longest in the position of a cross would win—which didn't have much cultural success either (Bartlett, 1986, p. 9).
} 
OATHS, ORDEALS, AND LIE DETECTORS

makes it socially acceptable to inflict costs on an individual, as the costs appear linked to a verdict of guilt or innocence (as in the case of oaths with supernatural punishments).

If the ordeal rests on the same psychological mechanisms as the oath with supernatural punishment, it offers two other advantages. First, the resolution is immediate rather than delayed until a misfortune has passed, or failed to pass within a specified timeframe. Second, ordeals impose a high fixed cost, whether they are passed or failed (i.e. the pain from burning or poisoning). Overall, the ordeal involves three different costs: the fixed cost of undergoing the ordeal itself, the extra cost that makes it diagnostic (e.g. the infection on the wound), and the penalty inflicted on those deemed guilty by the ordeal. Only the latter cost is also found in oaths, and then typically after a delay.

Because ordeals are much costlier than oaths, they serve a different role, making them more akin to punishment, as suggested by Bartlett and others. In many societies, ordeals can be imposed by powerful individuals on those lower down the social ladder (early medieval Europe: Hyams, 1981, p. 123; Olson, 2000, p. 121; Nzakara: Retel-Laurentin, 1969, p. 25; ancient Hindu law:Rocher, 1964, p. 368). Members of higher classes (such as the clergy in early medieval Europe, Bartlett, 1986; Frenchmen in England shortly after the conquest, Hyams, 1981, p. 112; or kings, chiefs, and their relatives among the Nzakara, Retel-Laurentin, 1969) are sometimes excluded from the ordeal. In other societies, the ordeal is largely reserved for people of ill-repute (early medieval Europe: Bartlett, 1986, p. 64; Hyams, 1981, p. 107; Visigoths: Peters, 1996, pp. 47-48). Note that the use of ordeals as punishment is not incompatible with the observation that many accused successfully passed the ordeal, as the ordeal itself, whether it was passed or failed, was already a severe punishment. 


\section{OATHS, ORDEALS, AND LIE DETECTORS}

As noted above the ordeal is typically absent when one party is all-powerful. When one party holds enough power, it can mete out punishments at will, without the help of intuitions about immanent justice to make a punishment more acceptable. Instead, when ordeals exist, the power to impose them is typically tampered by the opinion of politically influential community members, so that the ordeal tends to reflect a balance between the influence of those nominally in charge, and the broader community. In many cases it is this broader consensus that is the main driver of the ordeal, expressing itself through courts or specialized agents (e.g. medicine men). For example, in early medieval England, the hot iron ordeal was mostly practiced on accused for whom the community harbored "little ... doubt of ... guilt" (Kerr et al., 1992, p. 594). Likewise, among the Nzakara, who undergoes the ordeal, and even the outcome of the ordeal, typically accords with the wishes of those in a position to impose the ordeal, whether it be the king or the community at large (Retel-Laurentin, 1969, pp. 26, 76). As Fisher put it, "the institutional brilliance of the ordeal was that it so neatly merged the appearance of divine judgment with the reality of a great measure of human control" (Fisher, 1997, p. 601). In line with the conflict resolution/consensus building view, consensus plays an important role in the administration of ordeals. However, rather than building consensus, ordeals build on a pre-existing consensus.

Even if ordeals are generally imposed on accused who must either take them or confess their guilt, people can also choose to undergo the ordeal to prove their innocence, or obtain a favorable verdict more generally. When the ordeal is a choice, we find powerful members of the society, "concubines desiring to establish paternity, warring monarchs at an impasse, and queens suspected of infidelity offering to undergo, and undergoing [ordeals]" (Olson, 2000, p. 128; for early medieval Europe, see also Hyams, 1981, p. 125; medieval Iceland: Miller, 1988, p. 200). For the party who offers to undergo the ordeal, its high cost makes it a credible 
OATHS, ORDEALS, AND LIE DETECTORS

way of indicating the importance of a certain outcome, which helps explain why ordeals were accepted even when not imposed by those in power, or by the community at large. The relative versatility of the ordeal, which could be used "to condemn that unnamed villager who irritated his leaders, ... to quash that unjust theft allegation or to win that desirable water meadow" would have contributed to its cultural success (Hyams, 1981, p. 125).

\section{Lie detectors}

Besides ordeals in the restricted sense used above, many other practices have been referred to as ordeals, most famously the cold water ordeal, in which the accused was plunged in water, with floating indicating guilt and (temporarily) sinking innocence (e.g. Kerr et al., 1992). I group these practices under the umbrella of lie detectors. Lie detectors are practices - and their accompanying devices - that aim at establishing, based on some involuntary reaction, whether someone is telling the truth or not (or, more generally, whether someone is guilty or not). Lie detectors share two commonalities with ordeals in the restricted sense. First, they offer an immediate verdict. Second, they tap into some intuitions that make a given outcome appear diagnostic of lying. However, by contrast with ordeals, lie detectors do not tap into intuitions of immanent justice. Instead, lie detectors rely on a variety of intuitions, some possibly universal, others culture-specific. The fact that lie detectors fail to trigger immanent justice intuitions explains, I suggest, why they entail either no fixed cost, or a moderate fixed cost (by contrast with ordeals and their high fixed cost of burning or poisoning). Typically, the fixed costs of lie detectors take the form of discomfort (e.g. being plunged in cold water) and humiliation (doing so naked and in public) (Kerr et al., 1992; Segrave, 2004). 
OATHS, ORDEALS, AND LIE DETECTORS

Throughout history, humans have come up with a bewildering variety of lie detectors, by contrast with the very limited range of ordeals. The most common forms of lie detectors rest on seemingly widespread intuitions about cues to deception. Experiments on lie detection show that Western participants, when asked how they can spot a liar, cite a number of unreliable cues, such as fidgeting and gaze aversion (Hartwig \& Bond, 2011). Broadly, it seems that participants equate cues to nervousness with cues to deception. These findings have been replicated with Jordanian participants (Al-Simadi, 2000; Bond, Omar, Mahmoud, $\&$ Bonser, 1990). To the best of my knowledge, there is no experimental evidence showing that people use similar cues to deception in other cultures. However, historical evidence shows that judges in different times and places have claimed a likely non-existent ability to detect deception from demeanor (Qing China: Conner, 2000, p. 142; ancient India: Rocher, 1964, p. 346; European Middle Ages: Ullmann, 1946; $20^{\text {th }}$ century U.S.: Underwood, 1995, p. 622ff).

The intuitive link between nervousness and deception, even if fallacious, supported some of the most popular lie detectors. Associating a dry mouth with nervousness, medieval Europeans (Colman, 1974, p. 582), ancient Hindus (Trovillo, 1938, p. 853), and possibly ancient Chinese (Underwood, 1995, p. 614) had suspects chew on some dry food (rice, cornbread). If they chocked on it, or if they spat it out dry, they were thought to be lying. Modern lie detectors (polygraphs) rest on a similar logic. The autonomic variables they record - from pulse to skin conductance - measure arousal, which is linked with nervousness (rather than deception, hence their low reliability) (Segrave, 2004).

Other lie detectors proved culturally successful for different reasons. Several lie detectors rely on culturally idiosyncratic associations between a given outcome and guilt, but they tap into 
OATHS, ORDEALS, AND LIE DETECTORS

the psychology of disgust in one way or another, making them more likely to persist (see above). For example, among the Kikuyu, the medicine-man would hold a small animal to the nostrils of the accused, whom it would bite if they were guilty (Routledge \& Routledge, 1910, p. 213). Some children observed by the Opie would draw their fingers on the ground; if the finger was clean, it meant the child had lied (Opie \& Opie, 2001, pp. 127-128).

The so-called cold water ordeal persisted across millennia, from the Hittites in the second millennium BCE (Klíma, 1964) to $18^{\text {th }}$ century Europe and America (Bartlett, 1986, p. 149). It did so in spite of not triggering intuitions about immanent justice: the intuitively worse outcome, sinking, was associated with innocence. Instead, this lie detector relies on beliefs about the purity of water, supposed to reject the guilty by making them float. These beliefs being more idiosyncratic, the cold water ordeal never met the widespread cultural success of the ordeals in a restricted sense (burning, scalding, poison). It is plausible that the cold water ordeal owed part of its success to its public, spectacular nature, and even maybe to the nudity involved (making it memorable both for the victim and the onlookers) (Kerr et al., 1992, p. $581)$.

Finally, we also find a number of lie detectors that seem to rely entirely on culturally idiosyncratic beliefs and practices. As mentioned at the beginning, the Manua used coconuts. Among the Shona, a man being beat up by a woman, with her own underwear, was believed to be unable to lie (Holleman, 1975, p. 84). Medieval Icelanders had a suspect walk under a raised patch of grass; if it fell down on them, the suspect was thought to be lying (Miller, 1988, p. 201). Ancient Hindus would weigh the accused, the judge would speak with him for a little while, he was weighed again and, if found to be lighter than before, acquitted (Trovillo, 1938, p. 851). Throughout the $20^{\text {th }}$ century, a variety of lie detectors have been 
OATHS, ORDEALS, AND LIE DETECTORS

developed in the U.S., relying on anything from the lack of tremor in the voice to brain activity. Some of these variants on the polygraph became widely used, in spite of the lack of evidence demonstrating their accuracy (Segrave, 2004).

In spite of their lack of reliability, lie detectors are useful in that, like oaths and ordeals, they allow the infliction or the payment of a cost apparently linked to the facts of the matter. There is the relatively small fixed cost of undergoing the lie detector itself-the discomfort and humiliation. But the more important cost is that associated with being found to have lied—as in the case of the oaths. Given that the outcome of the lie detector is, as a rule, not under the control of those who take it, anyone who takes a lie detector has a chance of paying that cost. That someone is willing to take the chance to pay the cost of being found guilty reveals how important a positive verdict is for them. It is plausible that polygraphs were used in this manner by many companies in the U.S.: not to screen out liars or dishonest employees, but to screen out people not motivated enough to work for a given employer (Segrave, 2004). This means for instance that spies, who are deceptive but highly motivated, should not be picked up by lie detectors - and indeed they do not seem to be (Segrave, 2004, pp. 52-53, 173).

Even if, as a rule, lie detectors are imposed by some authorities, at least in some cultures it is also possible for a suspect to voluntarily submit to one (as in the case of modern polygraphs, Segrave, 2004), just as people can volunteer to undergo an ordeal, or offer an oath. The logic is the same: lie detectors give people the opportunity to pay a cost to show their willingness to obtain a given verdict. As in the case of oaths and ordeals, this versatility — being useful both for those in power and for those without any other recourse-would have contributed to the cultural success of lie detectors. 


\section{Conclusion}

Even though they have no or little power to discern liars from truth tellers, oaths, ordeals, or lie detectors are used in a wide range of societies to adjudicate in trials. I have suggested that these practices owe their cultural success to the way they trigger some cognitive mechanisms, making them more culturally attractive.

Oaths, as they are used generally, outside of judicial contexts, trigger cognitive mechanisms related to commitment. These mechanisms lead us to pay attention to, remember, and want to talk about oaths, as they reflect socially salient events. The same mechanisms drive us to use oaths when in need of communicating a very strong degree of commitment.

If the psychology of commitment provides the background for the broad cultural success of oaths, it cannot fully account for their judicial use, in particular when they play a decisive role. I suggested then that oaths can be used as power moves, but this does not explain the recurrent link between oaths and supernatural punishments. The role of supernatural punishments would be explained by intuitions of immanent justice. These intuitions would create a focal point, allowing the community to decide that an oath taker who suffers a misfortune perjured themselves. The link between misfortune and perjury means that all oath takers pay a cost when they take the oath (even if the cost is probabilistic), and that this cost is perceived a morally justified. The cost paid by oath takers allows them to prevail in the conflict, in part by assuaging the other party. 
OATHS, ORDEALS, AND LIE DETECTORS

Ordeals rely on the same logic. Intuitions about immanent justice link a worse outcome following the ordeal with a guilty verdict. This link helps justifies the application of the ordeal, which is what really matters, as the cost paid simply by enduring the ordeal acts as sufficient punishment in many cases.

Lie detectors rely on the same broad logic: the creation of a link between a given outcome and a guilty verdict. This link justifies the application of the lie detector, which entails a small fixed cost (discomfort, humiliation, as a weak form of ordeal), and a probabilistic cost (if found to have lied, as for oaths). However, by contrast with oaths and ordeals, lie detectors do not rely on intuitions about immanent justice. Instead, they rely on a variety of intuitions, some of which might be universal (the intuition linking nervousness with lying), while others are idiosyncratic (the belief that an upturned coconut indicates lying). The fact that lie detectors do not trigger intuitions of immanent justice would explain why lie detectors entail small fixed costs compared to ordeals, and why they were less cross-culturally successful.

We see in these practices the interplay of global cognitive attractors (intuitions about immanent justice, which are arguably universally developing, see Baumard et al., 2013; Baumard \& Chevallier, 2012), and local cognitive attractors (the local symbolic value of coconuts). Although I have not discussed them much, ecological factors also play a role. For example Roberts noted, in relation with the hot water ordeal, "boiling is a common process throughout the world and stone boiling, in particular, seems to provide an antecedent cultural context where ordeals could be discovered since this technique involves dealing with objects, that is, stones, immersed in boiling water" (1965, p. 206). 
Besides the specific cognitive factors that, I suggest, have helped oaths, ordeals, and lie detectors be culturally successful, more general features would also have helped them spread and persist. As noted by Morin (2016), redundancy is crucial for cultural elements to persist in the face of transmission noise. As they were practiced in purely or mostly oral societies, oaths, ordeals, and lie detectors were highly public affairs, witnessed and then discussed by many. The versatility of these practices, in particular the fact that, in many cultures, they could be either imposed at the will of powerful community members, or volunteered by people who had reached a judicial impasse, made them more widely relevant.

As noted in the introduction, although I have attempted to cover as much ground as possible, the present survey of the forms taken by oaths, ordeals, and lie detectors across the world, and at different times, remains informal. ${ }^{12}$ Future work could test the present hypotheses by proceeding to a more systematic survey of the anthropological and historical record, and by conducting laboratory experiment to test the role played by specific cognitive mechanisms (for an example with bloodletting, see Miton et al., 2015). ${ }^{13}$

\footnotetext{
${ }^{12}$ In part thanks to the resources provided by eHRAF.

${ }^{13}$ Unfortunately, compared to bloodletting, ordeals and lie-detectors are relatively rare, making it more difficult to apply systematic comparisons.
} 


\section{References}

Aikhenvald, A. Y. (2004). Evidentiality. Oxford: Oxford University Press.

Allott, A. (1964). Evidence in african customary law. Recueil de La Société Jean Bodin, 18, 59-80.

Al-Simadi, F. A. (2000). Jordanian students' beliefs about nonverbal behaviors associated with deception in Jordan. Social Behavior and Personality: An International Journal, 28(5), 437-441.

Bahrami, B., Olsen, K., Latham, P. E., Roepstorff, A., Rees, G., \& Frith, C. D. (2010). Optimally interacting minds. Science, 329(5995), 1081-1085.

Balliet, D. (2010). Communication and cooperation in social dilemmas: A meta-analytic review. Journal of Conflict Resolution, 54(1), 39.

Bartlett, R. (1986). Trial by fire and water: The medieval judicial ordeal. New York:

Clarendon Press Oxford.

Basden, G. T. (1966). Niger Ibos: A description of the primitive life, customs and animistic beliefs, etc., of the Ibo people of Nigeria. London: Cass.

Baumard, N., André, J. B., \& Sperber, D. (2013). A mutualistic approach to morality: The evolution of fairness by partner choice. Behavioral and Brain Sciences, 36(01), 59-78.

Baumard, N., \& Boyer, P. (2013a). Explaining moral religions. Trends in Cognitive Sciences, 17(6), 272-280.

Baumard, N., \& Boyer, P. (2013b). Religious beliefs as reflective elaborations on intuitions: A modified dual-process model. Current Directions in Psychological Science, 22(4), 295300 .

Baumard, N., \& Chevallier, C. (2012). What goes around comes around: The evolutionary roots of the belief in immanent justice. Journal of Cognition and Culture, 12(1-2), 67-80. Beattie, J. (1960). Bunyoro: An African kingdom. London: Harcourt College Pub.

Bibas, S. (2002). Harmonizing Substantive-Criminal-Law Values and Criminal Procedure:

The Case of Alford and Nolo Contendere Pleas. Cornell L. Rev., 88, 1361.

Boehm, C. (1999). Hierarchy in the Forest: The Evolution of Egalitarian Behavior.

Cambridge: Harvard University Press.

Boehm, Christopher. (1987). Blood revenge: The enactment and management of conflict in Montenegro and other tribal societies. Philadelphia: University of Pennsylvania Press.

Bond, C. F., Omar, A., Mahmoud, A., \& Bonser, R. N. (1990). Lie detection across cultures. Journal of Nonverbal Behavior, 14(3), 189-204.

Bonner, R. J. (1905). Evidence in Athenian courts. Chicago: University of Chicago Press. Boyer, G. (1964). La preuve dans les anciens droits du proche-Orient. Recueil de La Société Jean Bodin, 18, 62-87.

Boyer, P. (in press). Why divination? Evolved psychology and strategic interaction in the production of truth. Current Anthropology.

Boyer, P. (2001). Religion Explained. London: Heinemann.

Brown, P. (1975). Society and the supernatural: A medieval change. Daedalus, 133-151. Brunschvig, R. (1964). Le système de la preuve en droit musulman. Recueil de La Société Jean Bodin, 18, 169-186.

Callan, M. J., Ferguson, H. J., \& Bindemann, M. (2013). Eye movements to audiovisual scenes reveal expectations of a just world. Journal of Experimental Psychology: General, $142(1), 34$. 
Callan, M. J., Sutton, R. M., \& Dovale, C. (2010). When deserving translates into causing: The effect of cognitive load on immanent justice reasoning. Journal of Experimental Social Psychology, 46(6), 1097-1100.

Callan, M. J., Sutton, R. M., Harvey, A. J., \& Dawtry, R. J. (2014). Immanent justice reasoning: Theory, research, and current directions. In Advances in experimental social psychology (Vol. 49, pp. 105-161). Elsevier.

Charness, G., \& Dufwenberg, M. (2006). Promises and partnership. Econometrica, 74(6), 1579-1601.

Claidière, N., Smith, K., Kirby, S., \& Fagot, J. (2014). Cultural evolution of systematically structured behaviour in a non-human primate. Proceedings of the Royal Society B: Biological Sciences, 281(1797), 20141541.

Claidière, N., \& Sperber, D. (2007). The role of attraction in cultural evolution. Journal of Cognition and Culture, 7(1-2), 1-2.

Colman, R. V. (1974). Reason and unreason in early medieval law. The Journal of Interdisciplinary History, 4(4), 571-591.

Conner, A. W. (2000). True confessions? Chinese confessions then and now. In K. G. Turner, J. V. Feinerman, \& R. K. Guy (Eds.), The Limits of the Rule of Law in China (pp. 132-62). Seattle: University of Washington Press.

Cory, H., \& Hartnoll, M. M. (1945). Customary Law of the Haya Tribe, Tanganyika Territory (Vol. 7). London: Frank Cass \& Co.

Curtis, V., Aunger, R., \& Rabie, T. (2004). Evidence that disgust evolved to protect from risk of disease. Proceedings of the Royal Society of London. Series B: Biological Sciences, 271(Suppl 4), S131-S133.

Czekanowski, J. (1917). Investigations in the area between the Nile and the Congo: First volume: Ethnography, the interlacustrine region of Mporo and Ruanda. Leipzig: Klinkhardt \& Biermann.

Davies, W., \& Fouracre, P. (1992). The settlement of disputes in early medieval Europe.

Cambridge: Cambridge University Press.

Diamond, A. S. (2004). Primitive law, past and present (Kindle edition). London: Routledge.

Eriksson, K., \& Coultas, J. C. (2014). Corpses, maggots, poodles and rats: Emotional selection operating in three phases of cultural transmission of urban legends. Journal of Cognition and Culture, 14(1-2), 1-26.

Erskine, A., Morley, S., \& Pearce, S. (1990). Memory for pain: A review. Pain, 41(3), 255265.

Evans-Pritchard, E. E. (1956). Nuer religion. Clarendon Press.

Evans-Pritchard, E. E. (1957). The Zande royal court. Brussels: Éditions Universitares.

Fisher, G. (1997). The jury's rise as lie detector. The Yale Law Journal, 107(3), 575-713.

Floyd, S., Norcliffe, E., \& San Roque, L. (Eds.). (2018). Egophoricity (Vol. 118). London: John Benjamins Publishing Company.

Fusaroli, R., Bahrami, B., Olsen, K., Roepstorff, A., Rees, G., Frith, C., \& Tylén, K. (2012). Coming to terms quantifying the benefits of linguistic coordination. Psychological Science, 0956797612436816.

Gluckman, M. (1967). The judicial process among the Barotse of Northern Rhodesia (Zambia). Manchester: Manchester University Press.

Goubert, L., Vlaeyen, J. W., Crombez, G., \& Craig, K. D. (2011). Learning about pain from others: An observational learning account. The Journal of Pain, 12(2), 167-174.

Griffiths, T. L., Kalish, M. L., \& Lewandowsky, S. (2008). Theoretical and empirical evidence for the impact of inductive biases on cultural evolution. Philosophical Transactions of the Royal Society of London B: Biological Sciences, 363(1509), 3503-3514. 
Hamidullah, M. (1964). La génèse du droit de la preuve en islam. Recueil de La Société Jean Bodin, 18, 187-200.

Harrison, A. R. W. (1971). The law of Athens (Vol. 2). Oxford: Clarendon Press.

Hartwig, M., \& Bond, C. H. (2011). Why do lie-catchers fail? A lens model meta-analysis of human lie judgments. Psychological Bulletin, 137(4), 643.

Heath, C., Bell, C., \& Sternberg, E. (2001). Emotional selection in memes: The case of urban legends. Journal of Personality and Social Psychology, 81(6), 1028.

Holleman, J. F. (1975). Some Problems of Evidence in Shona Tribal Law. In M. Fortes \& S. Patterson (Eds.), Studies in African Social Anthropology (pp. 75-94). London: Academic Press.

Hyams, P. R. (1981). Trial by ordeal: The key to proof in the early common law. In M. S. Arnold, T. A. Green, S. A. Scully, \& S. D. White (Eds.), On the laws and customs of England: Essays in honor of Samuel E. Thorne (pp. 90-126). Chapel Hill: University of North Carolina Press.

Ishii, R. (1964). The history of evidence in japan. Recueil de La Société Jean Bodin, 18, 521534.

Jacquemet, N., Luchini, S., Shogren, J. F., \& Zylbersztejn, A. (2018). Coordination with communication under oath. Experimental Economics, 21(3), 627-649.

Kerr, M. H., Forsyth, R. D., \& Plyley, M. J. (1992). Cold water and hot iron: Trial by ordeal in England. The Journal of Interdisciplinary History, 22(4), 573-595.

Kirby, S., Cornish, H., \& Smith, K. (2008). Cumulative cultural evolution in the laboratory: An experimental approach to the origins of structure in human language. Proceedings of the National Academy of Sciences, 105(31), 10681-10686.

Klíma, J. (1964). La preuve dans le droit hittite. Recueil de La Société Jean Bodin, 18, 89102.

Lebzelter, V. (1934). Native cultures in southwest and south Africa, vol. 2. Leipzig: Karl W. Hiersemann.

Leeson, P. T. (2011). Trial by battle. Journal of Legal Analysis, 3(1), 341-375.

Leeson, P. T. (2012). Ordeals. The Journal of Law and Economics, 55(3), 691-714.

Leeson, P. T., \& Coyne, C. J. (2012). Sassywood. Journal of Comparative Economics, 40(4), 608-620.

Lévy, J. P. (1964). Le problème de la preuve dans les droits savants du Moyen-Age. Recueil de La Société Jean Bodin, 18, 137-167.

Logue, A. W., Ophir, I., \& Strauss, K. E. (1981). The acquisition of taste aversions in humans. Behaviour Research and Therapy, 19(4), 319-333.

Mahr, J., \& Csibra, G. (2017). Why do we remember? The communicative function of episodic memory. Behavioral and Brain Sciences, 1-93.

Mead, M. (1969). Social organization of Manua. Honolulu: Bishop Museum Press.

Meek, C. K. (1937). Law and authority in a Nigerian tribe: A study in indirect rule. New York: Barnes \& Noble.

Mercier, H. (in press). Not Born Yesterday: The Science of Who we Trust and What we Believe. New York: Princeton University Press.

Mercier, H. (2017). How gullible are we? A review of the evidence from psychology and social science. Review of General Psychology, 21(2), 103.

Meyer, H. (1916). The Barundi: An Ethnological Study from German East Africa. Leipzig:

Ott Spamer.

Middleton, J. (1953). The Central Tribes of the North-eastern Bantu: The Kikuyu, Including

Emlu, Meru, Mbere, Chuka, Mwimbi, Thanaka, and the Kamba of Kenya. London:

International African Institute.

Miller, W. I. (1988). Ordeal in Iceland. Scandinavian Studies, 189-218. 
Miton, H., Claidière, N., \& Mercier, H. (2015). Universal cognitive mechanisms explain the cultural success of bloodletting. Evolution and Human Behavior, 36(4), 303-312.

Morin, O. (2013). How portraits turned their eyes upon us: Visual preferences and demographic change in cultural evolution. Evolution and Human Behavior, 34(3), 222-229. Morin, O. (2016). How Traditions Live and Die. New York: Oxford University Press. Morley, S. (1993). Vivid memory for 'everyday'pains. Pain, 55(1), 55-62.

Murdock, G. P. (1980). Theories of illness: A world survey. Pittsburgh: University of Pittsburgh Press.

Nichols, S. (2002). On the genealogy of norms: A case for the role of emotion in cultural evolution. Philosophy of Science, 69(2), 234-255.

Olson, T. (2000). Of enchantment: The passing of the ordeals and the rise of the jury trial. Syracuse Law Review, 50, 109-196.

Opie, I. A., \& Opie, P. (2001). The lore and language of schoolchildren. Oxford: Oxford University Press.

Ostrom, E., Walker, J., \& Gardner, R. (1992). Covenants with and without a sword: Selfgovernance is possible. The American Political Science Review, 404-417.

Peters, E. (1996). Torture: Expanded Edition. Philadelphia: University of Pennsylvania Press. Posner, R. A. (1998). An economic approach to the law of evidence. Stan. L. Rev., 51, 1477. Ravenhill, D. W. (1953). Ordeal by Fire: An Eyewitness Account. Man, 53, 185-186. Reali, F., \& Griffiths, T. L. (2009). The evolution of frequency distributions: Relating regularization to inductive biases through iterated learning. Cognition, 111(3), 317-328. Retel-Laurentin, A. (1969). Oracles et ordalies chez les Nzakara (Vol. 33). ra. Paris and the Hague: Mouton.

Reynolds, S. (1997). Kingdoms and communities in Western Europe, 900-1300. Oxford: Oxford University Press.

Roberts, J. M. (1965). Oaths, autonomic ordeals, and power. American Anthropologist, 67(6), 186-212.

Roberts, S. (1979). Order and Dispute: An Introduction to Legal Anthropology. New York: St Martin's Press.

Rocher, L. (1964). The theory of proof in ancient Hindu law. Recueil de La Société Jean Bodin, 18, 325-371.

Roscoe, J. (1924). The Bagesu and other tribes of the Uganda protectorate. Cambridge: Cambridge University Press.

Routledge, W. S., \& Routledge, K. (1910). With a prehistoric people: The Akikuyu of British East Africa (Vol. 63). London: Edward Arnold.

Rozin, P., \& Fallon, A. (1987). A perspective on disgust. Psychological Review, 94, 23-41.

Russell, M. J. (1959). Hired Champions. Am. J. Legal Hist., 3, 242.

Schapera, I. (1955). A handbook of Tswana law and custom. London: Oxford University Press.

Schelling, T. C. (1960). The strategy of conflict. Cambridge, MA.: Harvard University Press. Segrave, K. (2004). Lie detectors: A social history. Jefferson: McFarland.

Sell, A., Sznycer, D., Al-Shawaf, L., Lim, J., Krauss, A., Feldman, A., ... Tooby, J. (2017). The grammar of anger: Mapping the computational architecture of a recalibrational emotion. Cognition, 168, 110-128.

Sell, A., Tooby, J., \& Cosmides, L. (2009). Formidability and the logic of human anger. Proceedings of the National Academy of Sciences, 106(35), 15073-15078.

Shack, W. A. (1979). Collective Oath Compurgation in Anglo-Saxon England and African states. European Journal of Sociology/Archives Européennes de Sociologie, 20(1), 1-18. Shweder, R., Much, N., Mahapatra, M., \& Park, L. (1997). Divinity and the "big three" explanations of suffering. Morality and Health, 119, 119-169. 
Silving, H. (1959). The oath: I. The Yale Law Journal, 68(7), 1329-1390.

Smith, E. W., \& Dale, A. M. (1920). The Ila-speaking peoples of northern Rhodesia (Vol. 2). London: MacMillan and Co.

Sperber, D. (1996). Explaining Culture: A Naturalistic Approach. Oxford: Blackwell. Sperber, D. (1997). Intuitive and reflective beliefs. Mind and Language, 12(1), 67-83. Sperber, D., Clément, F., Heintz, C., Mascaro, O., Mercier, H., Origgi, G., \& Wilson, D. (2010). Epistemic vigilance. Mind and Language, 25(4), 359-393.

Tenney, E. R., MacCoun, R. J., Spellman, B. A., \& Hastie, R. (2007). Calibration trumps confidence as a basis for witness credibility. Psychological Science, 18(1), 46-50.

Thomas, K. (1971). Religion and the Decline of Magic. London: Weidenfeld and Nicolson. Trovillo, P. V. (1938). History of lie detection. Am. Inst. Crim. L. \& Criminology, 29, 848. Ullmann, W. (1946). Medieval principles of evidence. Law Quarterly Review, 62, 77. Underwood, R. H. (1995). Truth Verifiers: From the Hot Iron to the Lie Detector. Ky. LJ, 84, 597.

Van Caenegem, R. C. (1965). The law of evidence in the twelfth century. In S. Kuttner \& J. J. Ryan (Eds.), Proceedings of the Second International Congress of Medieval Canon Law (Vol. 1). Wetteren: Cultural Press.

Van Caenegem, R. C. (1990). Reflexions on rational and irrational modes of proof in medieval Europe. Tijdschrift Voor Rechtsgeschiedenis, 58, 263.

Vullioud, C., Clément, F., Scott-Phillips, T. C., \& Mercier, H. (2016). Confidence as an expression of commitment: Why misplaced expressions of confidence backfire. Evolution and Human Behavior. 